\title{
DIARY OF EVENTS IN THE OIL MARKET, JANUARY 1971 - JUNE 1974'
}

\section{Frank Ellis*}

Until 1970, the international oil market was characterised by three distinguishing features which have an important bearing both on subsequent events in the oil market itself and on the more general considerations of the market organisation of trade, being debated in the aftermath of the major price increases of late 1973. These features were:

(a) Virtual total domination by seven companies (the oil "majors") which over the years carried out a quite open oligopolistic operation by setting an "official" international reference price between thems elves.

Net profits $1973^{2}$ US $\$ \mathrm{~m}$.

Esso, now Exxon

Royal Dutch/Shell

Texaco

Mobil Oil

Socal

Gulf Oil

$B P$
(USA)

(Anglo-Dutch)

(USA)

(USA)

(USA)

(USA)

(British)
2,443

1,694

1,292

849

844

800

763

(b) New discoveries of oil and the expansion of supply took place at

\footnotetext{
* Frank Ellis is a Research Officer of the Institute working on various aspects of trade in commodities and questions of trade and employment.

1 The introduction to this diary and description of events up to September 1973, were derived from B. Dasgupta The Oil Industry in India: Some Economic Aspects (Cass, 1971) and from a historical outline in J.M. Chevalier "The New Oil Game" (bi-monthly Contact March 1974).

Events between 1 September 1973 and the end of June 1974 were taken from press reports in The Financial Times and Times.

2 Net income for allocation. Source: Petroleum Economist, May 1974 p. 170. (Conversion for BP and Shell results at 1973 average rate of $\$ 2.32$ per $\mathfrak{x}$ ).
} 
a faster rate than the immediate increases in consumption. The market price of oil fell from about $\$ 2.20$ per barrel in 1948 to $\$ 1.80$ per barrel in the late 1950 s; followed by a more rapid decline in the mid 1960 s to as low as $\$ 1.25$ per barrel by $1970 .^{3}$

(c) Latterly (and particularly since 1960) the emergence of new forces which began gradually - though by no means dramatically to undermine the dominant position and "rules of the game" of the cartel. Amongst these were the formation of OPEC in 1960, originally comprising Venezuela, Iran, Iraq, Kuwait and Saudi Arabia, later joined by Qatar (1961), Libya and Indonesia (1962), Abu Dhabi (1967), Algeria (1969), and Nigeria (1971); and the emergence of independent operators outside the cartel (for example the Italian state company ENI; and the exploitation of new discoveries by firms such as Occidental). ${ }^{4}$

From 1970, events progressed rapidly in the direction of breaking up the situation outlined in (a). For the first time in two decades increases in demand began rapidly to outstrip the capacity for expanding production. At the same time there was an acceleration of the effectiveness of forces independent of the "majors".

In the diary which follows it should be borne in mind that it was the seven companies which determined posted prices between themselves prior to the 1970s. Producer countries could at best voice the opinion that such prices should be raised, and had made significant gains only in the taxation rates applicable to the profits of the companies ( $50 \%$ during the $1960 \mathrm{~s}$ ).

3 The actual international market price is related to the posted price via the taxation rate: it equals the tax paid cost of the oil to the companies plus their own production and distribution costs and margins. Thus in January 1970 the posted price was $\$ 1.80$ per barrel: with production and distribution costs of companies of $\$ 0.40$ approximately, and tax of $\$ 0.70$ (50\% of the profit of $\$ 1.40$ ) plus royalty of $\$ 0.23$ (121/2\% of the posted price), the international market price would be in the region of $\$ 1.33$ (and indeed was $\$ 1.30$ ). Unless otherwise stated, all prices given below relate to the reference quality of oil $\left(34^{\circ}\right.$ API. Saudi Arabian Light Oil fob Ras Tanura).

4 For a more complete description of events in the oil market in the 1950 s and 1960s see "Large International Firms in the Oil Industry" by Biplab Dasgupta in this issue. 


\section{January 1971}

Following the 21st Ministers Conference in December 1970, OPEC decided to try and reach agreement on harmonisation of prices and taxes, together with a general price rise. After difficulties in adopting a common approach, it was finally proposed to handle the issues by reaching agreement first on Persian Gulf arrangements (Teheran Agreement); and secondly on taxes and prices in the Mediterranean (Tripoli Agreement).

\section{February 1971 The Teheran Agreement}

Between six producer countries (Iran, Iraq, Saudi Arabia, Kuwait, Abu Dhabi, and Qatar) and the oil companies for Persian Gulf crude exports.

(a) Consolidated tax rates at $55 \%$ of companies' profits per barrel.

(b) Increase in posted prices by $\$ 0.38$ per barrel.

(c) Contractual settlement of increases in posted prices through to the end of 1975 ( $\$ 0.05$ per barrel increase in posted prices per annum).

This brought the posted prices of Persian Gulf oil from $\$ 1.80$ to $\$ 2.18$ per barrel.

\section{February 1971 The Tripoli Agreement}

Between the Mediterranean producing countries and the oil companies.

(a) Consolidated tax rates of $55 \%$.

(b) Posted price increase of $\$ 0.52$ per barrel of which $\$ 0.10$ was in respect of lower sulphur content of the oil $\left(40^{\circ} \mathrm{API}\right)$.

(c) A further increase of $\$ 0.25$ per barrel in respect of premiums related to lower freight costs (a "Suez premium" plus a further temporary freight premium).

(d) Annual increase of $\$ 0.05$ per barrel plus $2.5 \%$ of the posted price.

\section{August 1971}

The devaluation of the dollar diminished the real purchasing power of oil producers' revenues (posted prices being denominated in dollars). 
$8.49 \%$ in compensation for the international currency re-alignments of December 1971. Agreement contained a parity index designed to compensate for re-alignments in average exchange rates of nine industrial countries against the dollar.

October 1972

A Participation Agreement which had been under negotiation for nearly a year between some of the Arab oil producers and the companies with concessions in the Middle East was ratified by Saudi Arabia, Kuwait, Abu Dhabi and Qatar in New York. It included:-

(a) The progressive transfer to signatory states of $51 \%$ participation in concessions : $25 \%$ in 1973 for a total sum of $\$ 1$ billion; then $5 \%$ per annum from 1979 to 1982 and $6 \%$ in 1983 .

(b) The buying back by the companies of a part of the production accruing to host governments.

(c) Shared financing of oil development expenditures.

12 February 1973

A further $6 \%$ increase in posted price was negotiated under the Geneva Agreement by some producing countries. Algeria subsequently announced that changes in posted prices were a function of national sovereignty and did not require negotiation with the companies.

2 June 1973

Other OPEC countries negotiated a revision of the Geneva Agreement allowing for an immediate increase of $11.9 \%$ in posted prices to compensate for the second dollar devaluation, and a modification of the revision formula.

\section{September 1973}

Announcement of nationalisation of $51 \%$ of the assets of oil companies in Libya. Terms of participation rejected by the oil companies, and subject to continued negotiation.

\section{October 1973}

Beginning of Arab-Israeli hostilities.

\section{October 1973}

Negotiations in Venice between the major oil companies and the producing countries about further price increases were broken off. 


\section{October 1973}

Six Persian Gulf countries (Saudi Arabia, Kuwait, Iran, Iraq, Abu Dhabi and Qatar) decided in Kuwait to fix "unilaterally" (i.e. without recourse to negotiation with the companies) the posted price of $\$ 5.12$ per barrel; the market price equivalent $-\$ 3.65$ per barrel represented an increase of $17 \%$.

\section{October 1973}

OAPEC meeting in Kuwait decided that each member country should reduce its output by $5 \%$ per month from then onwards. An embargo was declared on exports to the USA and the Netherlands.

\section{November 1973}

OAPEC meeting in Kuwait decided to cut production by $25 \%$ from the "normal" October level (i.e. by 4.7 million barrels per day).

\section{December 1973}

OPEC announced posted prices of $\$ 11.65$ per barrel to come into effect from 1 January 1974. This price related to a revenue per barrel objective of $\$ 7.00$.

\section{January 1974}

New posted prices came into effect. Libya announced a price of $\$ 15.768$ per barrel calculated on the basis of the superior quality and geographical proximity of Libyan oil.

\section{8-30 January 1974}

A rush for bilateral deals with the Arabs by European countries, including:

(a) 8 January, Franco-Saudi deal.

(b) 21 January, Franco-Algerian deal.

(c) 23 January, German-Algerian deal.

(d) 25 January, British-Iranian deal.

(e) 27 January, Jobert (French foreign minister) makes statement in support of bilateral deals.

(f) 28 January, German-Iranian deal.

(g) 26-28 January, Jobert makes tour of Middle East offering general framework for long term bilateral deals with France. 
9 January 1974

Geneva Conference of OPEC decided to maintain the present prices of oil until 1 April, and to set up a commission responsible for formulating the establishment of a long term pricing system for crude oil.

28 January 1974

US Congress sub-committee (under Senator Frank Church) inquiry on the price policies and tax liabilities of oil companies began.

29 January 1974

Gulf Oil and BP signed a participation agreement with Kuwait. $60 \%$ of oil company interests to pass to the Kuwait state oil corporation.

\section{February 1974}

Kuwait offered $£ 48.7$ million - the pure book value of the assets for its $60 \%$ share in the oil industry.

2 February 1974

Statement by OPEC General Secretary (Abderrahman Khene) about the possibility of an OPEC $\$ 1,000$ million Arab Development Bank.

3 February 1974

Franco-Kuwait arms deal announced.

\section{February 1974}

Large Franco-Iranian deal involving a long term programme of collaboration in energy development and industrialisation announced on the eve of the Washington Conference of consumer countries.

\section{February 1974}

Libya announced outright nationalisation of the interests of three of the US companies (Texaco, Socal and Atlantic Richfield) which refused to accept the $51 \%$ participation of 1 September 1973.

\section{1-13 February 1974}

Washington Conference of the major oil consumers. Attempts to paper over the disunity between the main oil consumers (and particularly between the USA and the EEC) are dashed by French 
rejection of the conference as "an attempt by the consumers to impose their will on the rest of the world". The "watered down" US proposal emerged as:

(a) a code of conduct on bilateral deals,

(b) a co-operative solution on supplies and financial problems,

(c) a united approach to confront producers,

(d) a joint approach to the future role of oil companies.

In the event, there was a measure of success on (b), but none on (a), (c) or (d). France was not party to the final joint communique.

\section{February 1974}

Iran promised $\$ 1,000$ million to be shared between the World Bank and the IMF. Details to be worked out. Germany undertakes official investigations of the pricing policies of the companies (to be conducted by the Cartel Office).

\section{6-18 March 1974}

OPEC Conference announces:

(a) extension of present posted prices through to $1 \mathrm{July}$,

(b) lifting of oil embargo on the USA.

\section{March 1974}

US Congress sub-committee reveals ARAMCO net profits of $\$ 3,200$ million ("the largest profit ever made by a single company") in 1973, after deduction of taxes to the Saudi Arabian government of $\$ 3,930$ million, and US tax of only $\$ 2.8$ million.

28 March 1974

Saudi Arabia allows ARAMCO to boost production to 8.5 million barrels per day. An increase of 1.2 million barrels above the level set following production cut of 1 million barrels in September.

\section{April 1974}

UN General Assembly special session on the Problems of Raw Materials and Development begins. Speech on new world order and rights of LDCs by President Boumedienne of Algeria who had initiated the conference.

\section{April 1974}

Substantially increased profits announced by US companies for the first quarter of 1974, compared to corresponding period in 1973. 
Exxon

Texaco

Gulf

Standard Oil of

Indiana
$\$ 705$ m. (up 39\%)

$\$ 589$ m. (up $139 \%$ )

$\$ 290 \mathrm{~m} . \quad$ (up $76 \%$ )

$\$ 219$ m. (up $81 \%$ )

\section{May 1974}

Closing of the United Nations special session accompanied by the seven-point Declaration on the Establishment of a New International Economic Order, and the proposal to set up a Special Fund of $\$ 3,000$ million for the relief of those developing countries most seriously affected by balance of payments difficulties in 1974 .

\section{May 1974}

Announcement by IMF director, Dr. Johannes Witteveen that an IMF "oil facility" of $\$ 3,000$ million should be ready to assist the most seriously affected poor countries by mid-1974.

\section{May 1974}

EEC announces conditional proposal to contribute $\$ 500$ million to the UN Special Fund. Suggests that a further $\$ 1,000$ million should come from other developed countries and $\$ 1,500$ from the Arab oil producers.

\section{June 1974}

Discussion in OPEC regarding the determination of price levels for the next period. Saudi Arabia argues for a drop in posted prices to $\$ 9$ per barrel. Other oil producers meeting in Vienna recommend an increase of $\$ 1$ per barrel in the posted price and an increase in the tax rate from $55 \%$ to $87 \%$.

Arabs decide not to lift ban on shipments to Holland and Denmark.

\section{June 1974}

Ecuador Meeting of OPEC decides:

(a) posted price and tax rate to remain unchanged for a further three months from 1 July.

(b) a $2 \%$ increase in royalties to $14 \frac{1}{2} \%$ (having little effect because in most countries only a minority of the production is now owned by the companies and therefore liable for royalties). 